\title{
Analisis Faktor Eksternal dan Internal Terhadap Kinerja UMKM di Kota Batam
}

\author{
Mauli Siagian \\ Universitas Putera Batam \\ maulisgn@gmail.com \\ Putu Hari Kurniawan \\ Universitas Putera Batam \\ harryfebby@gmail.com

\section{Hikmah \\ Universitas Putera Batam} \\ Hikmahupb@gmail.com
}

\begin{abstract}
Abstrak
Sektor UMKM merupakan salah satu sektor penting untuk sumber perekonomian masyarakat Indonesia. Hal ini selain karena usaha tersebut merupakan tulang punggung sistem ekonomi kerakyatan yang tidak hanya ditujukan untuk mengurangi masalah kesenjangan antar golongan, pendapatan dan antar pelaku usaha, ataupun pengentasan kemiskinan dan penyerapan tenaga kerja. Dikota Batam kinerja sektor usaha mikro dan kecil (UMK) dipengaruhi oleh dua faktor utama yakni faktor-faktor eksternal dan faktor-faktor internal. Faktor internal meliputi aspek SDM (pemilik, manajer, dan karyawan), aspek keuangan, aspek teknis produksi; dan aspek pemasaran. Sedangkan Faktor eksternal terdiri dari kebijakan pemerintah, aspek sosial budaya dan ekonomi, serta peranan lembaga terkait seperti Pemerintah, Perguruan Tinggi, Swasta, dan LSM. Dalam penelitian ini bertujuan untuk mengetahui pengaruh eksternal dan internal terhadap kinerja usaha mikro, kecil dan menengah di Kota Batam. Populasi dalam penelitian ini adalah 2 kecamatan yang ada di Kota Batam yaitu Kecamatan Batu aji dan kecamatan Sagulung. Metode pengumpulan data mengunakan kuesioner. Sampel dalam penelitian ini 150 respoenden. Reseponden dalam penelitian ini adalah UMKM yang unit usahanya kuliner. Teknik penentuan sampel yang digunakan adalah purposive sampling. Adapun metode analisis yang digunakan mengunakan SEM dengan aplikasi SmartPLS. Hasil penelitian menunjukkan bahwa Faktor eksternal terdapat pengaruh terhadap faktor internal secara signifikan dan positif UMKM di Kota Batam; Faktor eksternal terdapat pengaruh terhadap Kinerja UMKM secara signifikan dan positif di Kota Batam; Faktor internal terdapat pengaruh terhadap Kinerja UMKM secara signifikan dan positif di Kota Batam.
\end{abstract}

Kata Kunci Faktor Eksternal, Faktor Internal dan Kinerja

\section{PENDAhuluan}

Pengembangan Usaha Mikro, Kecil dan Menengah (UMKM) di Indonesia merupakan salah satu aspek yang menjadi perhatian pemerintah dalam pembangunan ekonomi nasional. Hal ini selain karena usaha tersebut merupakan pondasi dr dalam system ekonomi kerakyatan yang tidak hanya ditujukan untuk mengurangi masalah ketimpangan pendapatan antar golongan dan antar masyarakat, ataupun permasalahan kemiskinan dan penyerapan tenaga kerja. Selain memiliki arti strategis bagi pembangunan, usaha kecil menengah juga berfungsi sebagai sarana dan prasarana untuk mendistribusikan hasil-hasil pembangunan yang telah dicapai (Lubanraja \& Lubis, 2017). Dalam perkembangan usaha mikro, kecil dana menengah banyak faktor yang mempengaruhi dalam pertumbuhannya (Montaseb, 2018).

Sektor UMKM merupakan sektor yang sangat strategis dalam perekonomian dan masyarakat Indonesia. Dikatakan demikian, mengingat sekitar 99\% usaha-usaha yang ada di Indonesia merupakan 
usaha yang dikategorikan sebagai UMKM. Selain itu, sektor UMKM tersebut meliputi berbagai usaha yang bersifat padat karya, sehingga sektor ini mampu melibatkan sejumlah besar tenaga kerja yang tersedia. Dengan kata lain, sektor UMKM merupakan sektor penting untuk sumber perekonomian masyarakat Indonesia. Jumlah unit UMKM mencapai 56.534.592 unit atau 99,9\% dari total unit usaha di Indonesia. Tenaga kerja yang mampu diserap oleh UMKM lebih dari 107.657.509 orang atau sebesar 97,16\% dari angkatan kerja. Kontribusi UMKM dalam pembentukan PDB mencapai Rp 4.870 triliun atau sebesar $59,08 \%$. Terkait dengan sumbangan dalam pembentukan nilai ekspor, UMKM menyumbang sebesar Rp 167 triliun atau sebesar 14,06\% (Amelia, Presetyo, \& Iswara, 2017).

Usaha mikro kecil menengah (UMKM) berkembang di Batam bukan hanya karena daerah industri tetapi juga di sebabkan karena Batam juga merupakan wilayah perbatasan dengan Singapura dan Malaysia. Ada beberapa pusat kawasan Industri yang ada banyak potensi pasarnya yaitu banyaknya pekerja yang tinggal di daerah tersebut seperti di wilayah Kecamatan Sagulung dan Kecamatan Batu Aji. Potensi pasar yang besar memicu dan menstimulasi para pengusaha untuk bisa bersaing memenuhi kebutuhan konsumen. Meskipun memiliki potensi yang cukup besar, UMKM belum mampu sepenuhnya mengantispasi tantangan usaha yang bergerak dinamis. Masalah utama yang dihadapi oleh UMKM adalah permodalan, pemasaran, bahan baku, teknologi, organisasi dan manajemen. Berdasarkan survei awal yang dilakukan, salah satu permasalahan yang dihadapi Usaha Mikro, kecil dan menengah adalah kurangnya pemahaman dan pemanfaatan informasi akuntansi dan pengelolaan keuangan yang belum teradministrasi dengan baik dimana pengelolaan keuangan belum dipisahkan antara keperluan usaha dan keperluan pribadi (rumah tangga). Dalam hal sumber daya manusia, permasalahan yang muncul berakitan dengan semangat entrepreneurship dimana kurangnya kesediaan untuk terus berinovasi, ulet tanpa menyerah serta semangat ingin mengambil resiko. Suasana santai yang menjadi latar belakang dari UMKM sering kali memiliki andil dalam membentuk kinerja. Bertolak dari latar belakang masalah tersebut di atas maka penelitian ini akan mengkaji tentang faktor eksternal dan faktor internal yang berpengaruh terhadap kinerja UMKM di kota Batam.

\section{LANDASAN TEORI}

\section{Kinerja Usaha}

Kinerja merupakan serangkaian dari berbagai kegiatan manajemen yang memberikan gambaran tentang sejauh mana hasil kegiatan yang sudah dicapai dalam melaksanakan tugas dan tanggung jawabnya dalam akuntabilitas publik baik berupa kemajuan, keberhasilan maupun kekurangan yang terjadi (Lanang, Kirya, \& Cipta, 2015). Kinerja adalah mengacu pada tingkat capaian prestasi perusahaan dalam jangka waktu tertentu. Kinerja (performance) pada perusahaan dapat dilihat dari tingkat penjualan perusahaan, tingkat margin, tingkat pengembalian modal, tingkat turn over dan pangsa pasar yang diraih (Sulistyowati \& Lestari, 2016).

Kinerja bisnis juga dapat dilihat pemilik usaha yang telah menanamkan modalnya pada suatu perusahaan memusatkan diri pada dua kriteria untuk mengukur kinerja perusahaan: 1) imbalan atas investasi modalnya dan 2) Risiko dari investasi modal mereka. Karena strategi bisnis yang harus dilaksanakan oleh manajer harus ditujukan untuk memuaskan pemilik bisnis. Para manajer harus menentukan strategi bisnis yang dilakukan akan berpengaruhi imbalan atas investasi modal perusahaan dan resikonya (Vidyatmoko, Husni, \& Rosadi, 2015). Pengukuran terhadap pengembalian investasi, pertumbuhan, volume penjualan, profit dan tenaga kerja yang ada pada perusahaan umumnya dilakukan untuk mengetahui kinerja perusahaan. Dalam kinerja UMKM beberapa faktor yang mempengaruhi (Lofian, 2016), (Purwaningsih \& Kusuma., Kusuma, 2016):

1. Pertumbuhan penjualan

2. Pertumbuhan Modal

3. Pertumbuhan tenaga kerja

4. Pertumbuhan pasar

5. Pertumbuhan Laba

\section{Faktor Internal}

Setiap kegiatan usaha yang dilakukan perusahaan tentuanya selalu dihadapkan pada situasi dan kondisi yang selalu berubah. Situasi dan Kondisi tersebut tidak mungkin dilaksanakan tanpa adanya proses penyesuaian terhadap kondisi eksternal dan internal yang ada. Jadi lingkungan internal merupakan cerminan kekuatan atau kelemahan dari suatu organisasi perusahaan dan dapat mencerminkan kemampuan manajemen untuk mengelola perusahaan. Hal ini dapat menunjukan kekuatan sumber daya, 
meliputi segala aspek material atau nonmaterial yang dimiliki perusahaan dalam menjalankan kegiatan usaha dan fungsinya untuk berproduksi secara komersial (Lofian, 2016). Adapun faktor internal yang mempengaruhi kinerja UMKM adalah sebagai berikut (Subroto, Hapsari, \& Astutie, 2016) :
a. Faktor Sumber Daya Manusia
b. Faktor keuangan
c. Faktor produksi
d. Faktor pemasaran

\section{Faktor Eksternal}

Lingkungan eksternal adalah faktor-faktor yang berada diluar kendali yang mempengaruhi perusahaan mengenai arah dan tindakan, yang pada akhirnya juga mempengaruhi struktur organisasi dan proses internalnya (Robbins \& Coulter, 2013). Lingkungan eksternal merupakan kondisi di luar perusahaan yang dapat mempengaruhi kehidupan perusahaan (Lofian, 2016) Faktor eksternal merupakan faktor-faktor yang berasal dari luar UMKM. Faktor tersebut bisa menghambat perkembangan UMKM. Dalam beberapa tahun kedepan akan terjadi berbagai dinamika bersifat eksternal yang akan berpengaruh terhadap perkembangan UMKM (Budiarto, 2015). Berbagai faktor eksternal tersebut meliputi sebagai berikut (Subroto et al., 2016):

1. Aspek kebijakan pemerintah sektor UMKM

2. Aspek sosial, budaya dan ekonomi

3. Aspek peranan Lembaga

\section{METODOLOGI PENELITIAN}

Metode yang digunakan dalam penelitian ini adalah metode survey. Metode survey bertujuan memperoleh gambaran umum tentang karakteristik atau berbagai aspek populasi yang berkaitan dengan permasalahan yang dikaji. Desain penelitian merupakan suatu metode atau prosedur untuk mengumpulkan data pada sebuah penelitian. Langkah awal dalam penelitian ini dengan melihat fenomena yang terjadi di Kota Batam, kemudian peneliti mengidentifikasi dan merumuskan tentang faktor yang mempengaruhi kinerja UMKM di Kota Batam. Sampel dalam penelitian ini adalah 150 orang yang dibagi kedalam 2 (dua) Kecamatan yaitu kecamatan Batu aji dan Sagulung. Teknik penentuan sampel purposive sampling. UMKM yang dijadikan sampel adalah UMKM yang usaha poduk kuliner.

\section{HASIL PENELITIAN}

Pada Validitas konvergen (Convergent Validity) dipergunakan untuk mengetahui bagaimana validitas setiap hubungan antara indikator dengan konstruk maupun variabel latennya. Untuk menguji convergent validity menggunakan nilai outer loading atau loading factor. Suatu indikator dapat dikatakan memenuhi convergent validity sebagai golongan yang baik apabila nilai outer loading $>0,7$. Berikut adalah gambar hasil kalkulasi model SEM SmartPLS, selanjutnya dapat dilihat nilai loading factor indikator-indikator pada variabel berikut:

Tabel 1.. Outer loadings Faktor Eksternal

\begin{tabular}{|c|c|c|}
\hline Variabel & Indikator & Outer Loading \\
\hline \multirow{4}{*}{ Faktor Ekternal } & X1.1 & 0.782573 \\
\cline { 2 - 3 } & X1.3 & 0.783256 \\
\cline { 2 - 3 } & X1.4 & 0.832103 \\
\cline { 2 - 3 } & X2.1 & 0.715041 \\
\cline { 2 - 3 } & X3.3 & 0.732579 \\
\cline { 2 - 3 } & X3.4 & 0.714844 \\
\hline
\end{tabular}

Berdasarkan data dalam tabel 1 di atas, diketahui bahwa masing-masing indikator variabel penelitian banyak yang memiliki nilai outer loading $>0,7$. Data di atas menunjukkan tidak ada indikator variabel yang nilai outer loading-nya di bawah 0,5 , sehingga semua indikator dinyatakan layak atau valid untuk digunakan penelitian dan dapat digunakan untuk analisis lebih lanjut. Hal ini menyatakan bahwa memiliki tingkat validitas yang tinggi, sehingga memenuhi convergent validity. Dengan demikian analisis dapat diteruskan pada uji Discriminant Validity.

Tabel 2. Outer loadings Faktor Internal 


\begin{tabular}{|c|c|c|}
\hline Variabel & Indikator & Outer Loading \\
\hline \multirow{4}{*}{ Faktor Internal } & Y1.1 & 0.925349 \\
\cline { 2 - 3 } & Y1.2 & 0.882723 \\
\cline { 2 - 3 } & Y1.3 & 0.831201 \\
\cline { 2 - 3 } & Y1.4 & 0.776164 \\
\cline { 2 - 3 } & Y2.1 & 0.925349 \\
\cline { 2 - 3 } & Y2.2 & 0.882723 \\
\cline { 2 - 3 } & Y2.3 & 0.831201 \\
\cline { 2 - 3 } & Y2.4 & 0.825351 \\
\cline { 2 - 3 } & Y3.1 & 0.822723 \\
\cline { 2 - 3 } & Y3.2 & 0.825349 \\
\cline { 2 - 3 } & Y3.3 & 0.812723 \\
\cline { 2 - 3 } & Y3.4 & 0.831201 \\
\cline { 2 - 3 } & Y4.1 & 0.816164 \\
\cline { 2 - 3 } & Y4.2 & 0.915349 \\
\cline { 2 - 3 } & Y4.3 & 0.812723 \\
\hline
\end{tabular}

Berdasarkan data dalam tabel 2 di atas, diketahui bahwa masing-masing indikator variabel penelitian banyak yang memiliki nilai outer loading $>0,7$. Data di atas menunjukkan tidak ada indikator variabel yang nilai outer loading-nya di bawah 0,5 , sehingga semua indikator dinyatakan layak atau valid untuk digunakan penelitian dan dapat digunakan untuk analisis lebih lanjut. Hal ini menyatakan bahwa memiliki tingkat validitas yang tinggi, sehingga memenuhi convergent validity. Dengan demikian analisis dapat diteruskan pada uji Discriminant Validity.

Tabel 3. Outer loadings Kinerja

\begin{tabular}{|c|c|c|}
\hline Variabel & Indikator & Outer Loading \\
\hline \multirow{4}{*}{ Kinerja } & $\mathrm{Z} 1$ & 0.827849 \\
\cline { 2 - 3 } & $\mathrm{Z} 2$ & 0.817648 \\
\cline { 2 - 3 } & $\mathrm{Z3}$ & 0.876502 \\
\cline { 2 - 3 } & $\mathrm{Z} 5$ & 0.8526570 \\
\hline
\end{tabular}

Berdasarkan data dalam tabel 3 di atas, diketahui bahwa masing-masing indikator variabel penelitian banyak yang memiliki nilai outer loading $>0,7$. Data di atas menunjukkan tidak ada indikator variabel yang nilai outer loading-nya di bawah 0,5 , sehingga semua indikator dinyatakan layak atau valid untuk digunakan penelitian dan dapat digunakan untuk analisis lebih lanjut. Hal ini menyatakan bahwa memiliki tingkat validitas yang tinggi, sehingga memenuhi convergent validity. Dengan demikian analisis dapat diteruskan pada uji Discriminant Validity.

Discriminant validity dilakukan untuk memastikan bahwa setiap konsep dari masing variabel laten berbeda dengan variabel lainnya. Model mempunyai discriminant validity yang baik jika setiap nilai loading dari setiap indikator dari sebuah variabel laten memiliki nilai loading yang paling besar dengan nilai loading lain terhadap variabel laten lainnya. Berdasarkan hasil yang diperoleh tersebut, dapat dinyatakan bahwa indikator-indikator yang digunakan dalam penelitian ini telah memiliki discriminant validity yang baik dalam menyusun variabelnya masing-masing.

Selain meneliti nilai cross loading, discriminant validity juga dapat diketahui melalui metode lain yaitu dengan cara melihat nilai average variant extracted (AVE) untuk masing-masing indikator nilainya harus > 0,5 agar dapat dikatakan sebagai model yang baik.

Tabel 4 Average Variant Extracted (AVE)

\begin{tabular}{|c|c|c|}
\hline Variabel & AVE & Communality \\
\hline Faktor eksternal & 0.740178 & 0.640167 \\
\hline Faktor internal & 0.747016 & 0.754236 \\
\hline Kinerja UMKM & 0.691286 & 0.691356 \\
\hline
\end{tabular}


Berdasarkan tabel 4 diatas, diketahui bahwa faktor eksternal, faktor internal dan kinerja UMKM memiliki nilai average variant extracted $>0,5$. Dengan demikian dapat dikatakan setiap variabel telah memiliki discriminant validity yang baik. Nilai Communality lebih besar daripada daripada 0.5.

Composite Reliability merupakan bagian yang digunakan untuk menguji nilai reliabilitas indikatorindikator pada suatu variabel. Suatu variabel dapat dinyatakan memenuhi composite reliability apabila memiliki nilai composite reliability $>0,6$. Berikut ini adalah nilai composite reliability dari masingmasing variabel yang digunakan dalam penelitian ini:

Tabel 5. Composite Reliability

\begin{tabular}{|c|c|}
\hline Variabel & AVE \\
\hline Faktor eksternal & 0.927317 \\
\hline Faktor internal & 0.950012 \\
\hline Kinerja & 0.815632 \\
\hline
\end{tabular}

Berdasarkan sajian data pada tabel 5 di atas, dapat diketahui bahwa nilai composite reliability semua variabel penelitian >0,6. Hasil ini menunjukkan bahwa masing-asing variabel telah memenuhi composite realibility sehingga dapat disimpulkan bahwa keseluruhan variabel memiliki tingkat realibilitas yang tinggi.

Tabel 6 Cronbach Alpha

\begin{tabular}{|c|c|}
\hline Variabel & Cronbach Alpha \\
\hline Faktor eksternal & 0.879603 \\
\hline Faktor internal & 0.938032 \\
\hline Kinerja & 0.856719 \\
\hline
\end{tabular}

Berdasarkan sajian data di atas pada tabel 6, dapat diketahui bahwa nilai cronbach alpha dari masing-masing variabel penelitian >0,7. Dengan demikian hasil ini dapat menunjukkan bahwa masingmasing variabel penelitian telah memenuhi persyaratan nilai cronbach alpha, sehingga dapat disimpulkan bahwa keseluruhan variabel memiliki tingkat reliabilitas yang tinggi. Pada penelitian ini akan dijelaskan mengenai hasil uji path coefficient, uji goodness of fit dan uji hipotesis.

Evaluasi path coefficient digunakan untuk menunjukkan seberapa kuat efek atau pengaruh variabel independen kepada variabel dependen. Sedangkan coefficient determination ( $R$-Square) digunakan untuk mengukur seberapa banyak variabel endogen dipengaruhi oleh variabel lainnya. Chin menyebutkan hasil $\mathrm{R}$ sebesar 0,67 ke atas untuk variabel laten endogen dalam model struktural mengindikasikan pengaruh variabel eksogen (yang mempengaruhi) terhadap variabel endogen (yang dipengaruhi) termasuk dalam kategori baik. Sedangkan jika hasilnya sebesar 0,33-0,67 maka termasuk dalam kategori sedang, dan jika hasilnya sebesar $0,19-0,33$ maka termasuk dalam kategori lemah. nilai path coefficient terbesar terdapat pada pengaruh faktor eksternal terhadap faktor internal sebesar 20,459. Pengaruh terbesar kedua terdapat pada pengaruh faktor internal terhadap kinerja UMKM sebesar 4,536, pengaruh terbesar ketiga terdapat pada pengaruh faktor eksternal terhadap kinerja UMKM sebesar 0.715.

Berdasarkan analisis diatas, menjelaskan bahwa semua variabel pada model ini memiliki path coefficient dengan angka yang positif. Hal ini menjelaskan bahwa jika semakin besar nilai path coefficient pada variabel eksogen terhadap variabel endogen, maka semakin kuat pengaruh antar variabel eksogen terhadap variabel endogen tersebut. Berdasarkan pengolahan data yang telah dilakukan dengan menggunakan program smartPLS 2.0, diperoleh nilai $R$-Square sebagai berikut:

Tabel 7 R-Square

\begin{tabular}{|c|c|}
\hline Variabel & R-Square \\
\hline Faktor Eksternal & 0.647727 \\
\hline Faktor Internal & 0.691804 \\
\hline Kinerja UMKM & \\
\hline
\end{tabular}

Berdasarkan tabel 7 di atas, menjelaskan bahwa variabel Faktor eksternal tidak mempunyai nilai $R$-Square karena variabel tersebut tidak dipengaruhi oleh variabel lainnya. Selanjutnya nilai $R$-Square untuk variabel Internal sebesar 0.635727. Perolehan nilai tersebut menerangkan bahwa persentase 
besarnya faktor internal sebesar 63,57\%. Nilai $R$-Square untuk variabel kinerja UMKM sebesar 0,580409. Perolehan nilai tersebut menerangkan bahwa persentase besarnya kualitas pelayanan sebesar 58,04\%.

Berdasarkan pengolahan data yang telah dilakukan, hasil dari pengolahan data dapat digunakan untuk menjawab hipotesis pada penelitian ini. Uji hipotesis pada penelitian ini dapat dilihat melalui nilai $T$ Statistics dan nilai T-Tabel. Hipotesis pada penelitian ini dapat dinyatakan diterima apabila nilai T-Tabel $>1,96$. Untuk menilai signifikansi model, dapat dilihat dari nilai $t$-statistic antara variabel independen ke variabel dependen dalam tabel Path Coefficient pada output SmartPLS dibawah ini:

Tabel 8 T-Statistic

\begin{tabular}{|c|c|c|c|c|c|}
\hline & $\begin{array}{c}\text { Original } \\
\text { Sample (O) }\end{array}$ & $\begin{array}{c}\text { Sample } \\
\text { Mean (M) }\end{array}$ & $\begin{array}{c}\text { Standard } \\
\text { Deviation } \\
\text { (STDEV) }\end{array}$ & $\begin{array}{c}\text { Standard } \\
\text { Error } \\
\text { (STERR) }\end{array}$ & $\begin{array}{c}\text { T-Statistics } \\
(\mid \text { O/STERR|) }\end{array}$ \\
\hline $\begin{array}{c}\text { Faktor } \\
\text { Eksternal -> } \\
\text { Faktor internal }\end{array}$ & 0.78258 & 0.814714 & 0.045162 & 0.021161 & 18.5321 \\
\hline $\begin{array}{c}\text { Faktor } \\
\text { Eksternal -> } \\
\text { Kinerja } \\
\text { UMKM }\end{array}$ & 0.137801 & 0.256105 & 0.164519 & 0.179787 & 0.790891 \\
\hline $\begin{array}{c}\text { Faktor internal } \\
\text {-> Kinerja } \\
\text { UMKM }\end{array}$ & 0.73219 & 0.67688 & 0.124432 & 0.2168431 & 5.214196 \\
\hline
\end{tabular}

Berdasarkan hasil dari perhitungan statistik, dapat disimpulkan bahwa faktor eksternal berpengaruh positif dan signifikan terhadap faktor internal secara langsung. Hal ini dapat diketahui dari nilai T-Statistic yang lebih besar dari 1,96 yaitu sebesar 18.5321. Nilai original sample (O) adalah positif yaitu sebesar 0.782581. Dengan demikian, hipotesis H1 dalam penelitian ini diterima. Hal ini menjelaskan bahwa adanya pengaruh yang signifikan antara faktor eksternal dan internal. Faktor eksternal yaitu Aspek Kebijakan pemerintah, Aspek sosial, budaya, dan ekonomi, Aspek peranan lembaga terkait memiliki pengaruh terhadap perkembangan dalam UMKM pada faktor internal yaitu Aspek sumber daya manusia, Aspek keuangan, Aspek teknis produksi dan Operasi, Aspek pasar dan pemasaran. Dalam perkembangan UMKM kedua faktor tersebut sangat berpengaruh, terutama faktor eksternal misalnya seperti aspek kebijakan pemerintah, ketika pemerintah menetapkan kebijakan yang berkaitan dengan UMKM tentunya akan secara langsung berdampak pada faktor internal daripada perusahaan, begitu juga dengan aspek aspek eksternal yang lain. Kualitas dari faktor internal UMKM di Kota Batam dapat lebih ditingkatkan dan menjadi peluang untuk menjadi usaha yang lebih besar apabila faktor-faktor eksternal yang ada disekitar lingkungan UMKM memberi dukungan secara penuh. Hasil ini sesuai dengan hasil penelitian (Lanang et al., 2015), (Subroto et al., 2016), (Shinta wahyu Hati \& Irawati, 2016), (Munizu, 2016) mengatakan bahwa faktor eksternal berpengaruh terhadap faktor internal.

Berdasarkan hasil dari perhitungan statistik, dapat disimpulkan bahwa faktor eksternal berpengaruh positif dan signifikan terhadap Kinerja UMKM secara langsung. Hal ini dapat diketahui dari nilai T-Statistic yang lebih besar dari 1,96 yaitu sebesar 0.790891. Nilai original sample (O) adalah positif yaitu sebesar 0.137801 . Dengan demikian, hipotesis H2 dalam penelitian ini diterima. Hasil penelitian ini secara empiris menunjukkan bahwa para responden dalam penelitian ini berpendapat bahwa faktor eksternal terbukti tidak mempengaruhi kinerja UMKM secara signifikan. Hal ini mengindikasikan bahwa masih kurangnya faktor eksternal seperti kebijakan pemerintah dan peran lembaga terkait untuk meningkatkan kinerja UMKM di Kota Batam. Apabila faktor eksternal seperti aspek kebijakan pemerintah, Aspek sosial, budaya, dan ekonomi, Aspek peranan lembaga terkait mampu mendukung dan membantu para pelaku usaha UMKM dalam hal kebijakan pemerintah yang bersinergi dan didukung dengan sosial, budaya dan ekonomi yang lebih baik serta dukungan lembaga yang terkait akan lebih mampu meningkatkan kinerja UMKM yang lebih baik ke depannya. Pada variabel Faktor Eksternal untuk meningkatkan kinerja UMKM yaitu dengan keterlibatan pihak-pihak yang terkait baik dari dinas pemerintahan dan lembaga-lembaga yang memfasilitasi dengan memberikan bantuan peralatan atau pun media untuk proses secara keseluruhan dari segi bahan baku ,proses produksi dan proses pemasaran, sehingga UMKM dapat lebih kreatif dalam menghasilkan produk-produk unggulan yang berkualitas. 
Hasil ini sesuai dengan hasil penelitian (S. W. Hati \& Irawati, 2017) bahwa faktor eksternal tidak berpengaruh terhadap kinerja UMKM.

Berdasarkan hasil dari perhitungan statistik, dapat disimpulkan bahwa faktor internal berpengaruh positif dan signifikan terhadap Kinerja UMKM secara langsung. Hal ini dapat diketahui dari nilai $T$ Statistic yang lebih besar dari 1,96 yaitu sebesar 5.214196. Nilai original sample (O) adalah positif yaitu sebesar 0.73219. Dengan demikian, hipotesis H3 dalam penelitian ini diterima. Hasil penelitian ini secara empiris menunjukkan bahwa para responden dalam penelitian ini berpendapat bahwa faktor internal yang baik seperti aspek sumber daya manusia, aspek keuangan, aspek teknis dan operasional, serta aspek pasar dan pemasaran akan membantu para pemilik UMKM untuk mencapai pertumbuhan penjualan, modal, keuntungan, dan pasar. Hasil ini sesuai dengan hasil penelitian (Munizu, 2016), (Lofian, 2016) bahwa faktor-faktor internal memiliki pengaruh positif dan signifikan terhadap kinerja usaha.

\section{KESIMPULAN}

1. Faktor eksternal terdapat pengaruh terhadap faktor internal secara signifikan dan positif UMKM di Kota Batam.

2. Faktor eksternal tidak terdapat pengaruh terhadap Kinerja UMKM secara signifikan dan positif di Kota Batam.

3. Faktor internal terdapat pengaruh terhadap Kinerja UMKM secara signifikan dan positif di Kota Batam.

\section{DAFTAR PUSTAKA}

Amelia, M. N., Presetyo, Y. E., \& Iswara, M. (2017). E-UMKM: Aplikasi Pemasaran Produk UMKM Berbasis Android sebagai Strategi Meningkatkan Perekonomian Indonesia. Snatif, (4), 11-16.

Budiarto, R. (2015). Pengembangan UMKM antara konseptual dan pengalaman Prakts. Yogyakarta: Gadjah Mada University Press.

Lanang, I. P. E. S., Kirya, I. K., \& Cipta, I. W. (2015). Analisis Faktor-Faktor Yang Mempengaruhi Kinerja Usaha Mikro Kecil Dan Menengah (UMKM) Di Kabupaten Bangli. E-Journal Bisma Universitas Pendidikan Ganesha, 2(1), 11-21.

https://doi.org/https://media.neliti.com/media/publications/176529-ID-analisis-faktor-faktor- $\quad$-yangmempengaruhi.pdf

Lofian. (2016). Identifikasi Faktor Eksternal Dan Faktor Internal Yang Berpengaruh Terhadap Kinerja UKM Mebel dan Rotan di Jepara. Disprotek, 5(2), 8-15.

Lubanraja, P., \& Lubis, A. N. (2017). Pengembangan usaha Mikro kecil dan Menengah di Kota batam. Talenta, 2(4), 41-47.

Montaseb, M. M. (2018). The Factors Affecting of SMEs' Outsourcing Decision Making. The Business and Mana Gement Review, 9(3), 9-10.

Purwaningsih, R., \& Kusuma., Kusuma, P. D. (2016). Analisis Faktor-faktor Yang Mempengaruhi Kinerja Usaha Kecil dan Menengah (UKM) Dengan Metode Structural Equation Modeling (Studi kasus UKM berbasis Industri Kreatif Kota Semarang). Robbins, S. P., \& Coulter, M. (2013). Perilaku Organisasi. Jakarta: Erlangga.

Subroto, S., Hapsari, I. M., \& Astutie, Y. P. (2016). Analisis Faktor-Faktor Yang Mempengaruhi Kinerja Usaha Mikro Kecil Dan Menengah (Umkm) Kabupaten Brebes. Prosding Semnar Nasional Penelitian Dan PKM Sosal, Ekonomi Dan Humaniora, 337-344.

Sulistyowati, E., \& Lestari, N. S. (2016). Faktor Faktor penentu keberhasilan usaha kecil dan Menengah di Kota Yogyakarta. Jurnal MAKSIPRENEUR, VI(1), 24-36.

Vidyatmoko, D., Husni, A., \& Rosadi, Y. (2015). Faktor Utama Kesuksesan Wirausaha di Industri Pangan. Jurnal Manajemen Teknologi, 14(1), 47-65. 